\title{
‘n Reisjoernaal vir geestelike navigasie
}

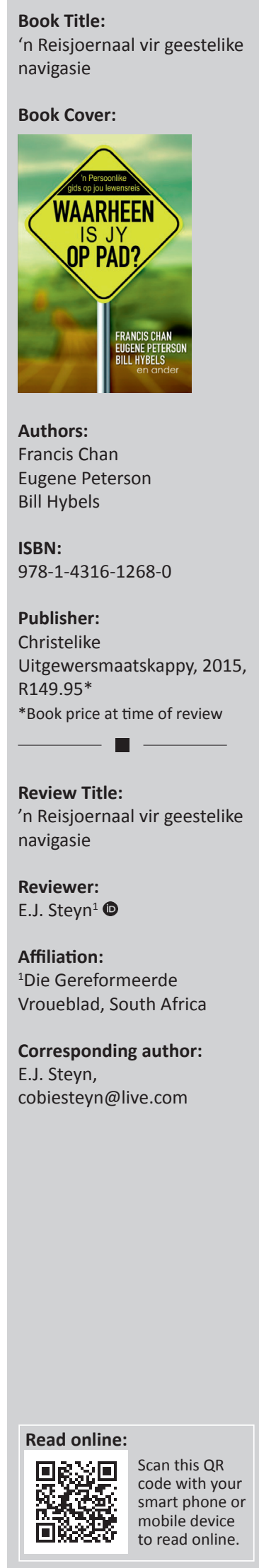

Waarheen is jy op pad? is 'n bundel met 13 bydraes deur (hoofsaaklik Amerikaanse) teoloë uit verskillende denominasies. Inleidend word dit duidelik gemaak dat elke gelowige graag wil weet wat sy of haar lewenspad vorentoe inhou, maar vir 'n mens se lewensreis kry jy ongelukkig nie 'n GPS-eenheid met 'n 'blou roetemerker' (bl. 7) nie. Dit is die Here wat 'n mens se lewensrigting bepaal en daarvoor kry jy riglyne slegs uit die Woord. Daarom noem die skrywers die boek '... 'n reisjoernaal, met idees en hulp oor hoe om die lewe te navigeer' (bl. 9).

Derhalwe word reisterme gebruik om die verskillende dele van die boek aan te dui: 'Padwaardig' (dl. 1); 'Noodsaaklike herstelwerk' (dl. 2); 'Verspoelings en ompaaie' (dl. 3); 'Reis lig' (dl. 4) en 'Versiende visie' (dl. 5). Elke deel bestaan uit 'n paar hoofstukke wat die betrokke tema belig (met elke hoofstuk telkens deur'n ander outeur). Aanvanklik het ek gewonder of 13 verskillende outeurs eenheid van gedagtegang en skryfstyl sou kon bewerkstellig, maar alles skakel naatloos ineen.

Omdat die boek uit 'n teologiese oogpunt geskryf is, sal dit in die eerste plek handig te pas kom vir predikante. Slegs enkele sake word uitgelig (daar is egter baie meer):

- leierskap in jou gemeente;

- die kerk wat enersyds té veel na binne gekeer en veroordelend is, en andersyds soms té akkommoderend teenoor die wêreld is;

- die behoefte by die predikant 'om ander mense te beheer en te behaag' (bl. 62) wat in 'n selfvernietigende obsessie kan ontaard;

- om versigtig met jou woorde om te gaan in jou bediening;

- hoe om lyding in jou eie lewe te verstaan en te hanteer sodat jy nie 'kwaad, bitter en vreugdeloos' (bl. 120) sal raak nie, maar jou eie pyn só sal hanteer dat jy in staat sal wees 'om God se waarde te demonstreer vir 'n wêreld wat toekyk' (bl. 118);

- om in slegte situasies 'wonderlike geleenthede' (bl. 137) te sien en te besef God gebruik dit tot sy eer;

- om gereeld te rus om so 'geestelike en emosionele leegheid' (bl. 158) uit te skakel;

- om eenvoudig te lewe en tevrede te wees met wie jy is en wat jy het; en

- om daarna te streef om 'n geestelike mentor vir lidmate te wees en hulle te begelei na 'geestelike volwassenheid' (bl. 189 e.v.).

Die boek kan ook aanbeveel word vir enige gelowige wat 'n begeerte het na geestelike verdieping. Die lidmaat wat hierdie boek lees, sal ook insig bekom oor die dinge waarmee predikante worstel en wat in hulle harte leef.

Op 'n paar plekke kon van die temas meer Skrifgefundeerd gewees het, byvoorbeeld op bladsy 41 (dl. 1, hfst 3) is die titel 'Vermy kulturele besmetting' 'n ongelukkige keuse vir 'n hoofstuk wat handel oor die identiteit van die kerk en die behoud van hierdie unieke identiteit in "n gekompromitteerde wêreld'. In die voorbeelde van Jona, Ester en Daniël wat daarna volg, word kategoriese stellings gemaak, byvoorbeeld dat 'Jona se teologiese familie die Fariseërs was' en Ester s'n 'die Saduseërs' (bl. 47). Die lyn tussen verskillende Skrifgedeeltes word nie behoorlik deurgetrek nie. Dus word die onderskeie Skrifgedeeltes nie volgens elkeen se eie aard hanteer nie en ongeldige vergelykings word getref.

Wanneer een van die medewerkers, Gordon MacDonald (dl. 4, hfst. 13), praat oor die noodsaaklikheid van rus, maak hy baie gewag van die Sabbat en hoe die hedendaagse belydende Jode soos Herman Wouk en Joseph Lieberman daaroor dink. Hoewel baie waarheidsmomente oor noodsaaklike rus vir die gelowige na vore kom, is daar 'n gemis aan die bybelse begronding daarvan, naamlik dat God die rus reeds by die skepping ingestel het; dat die sondeval ons 'rus

How to cite this book review: Steyn, E.J., 2016, "n Reisjoernaal vir geestelike navigasie', In die Skriflig 50(1), a2111. http://dx.doi. org/10.4102/ids.v50i1.2111

Copyright: (C) 2016. The Authors. Licensee: AOSIS. This work is licensed under the Creative Commons Attribution License. 
kom versteur het', maar dat ons die ewige rus in Christus verkry het. Die Hebreërbrief (vgl. hfst. 4) kon hier 'n sterk rugsteun gewees het.

Wanneer Mark Buchanan praat oor die strewe na 'n eenvoudige lewe (dl. 4, hfst. 14), is daar van pragtige ondersteunende Skrifgedeeltes gebruik gemaak, maar dit kon nog sterker uitgebou gewees het deur Paulus se '... ek het geleer om my in alle omstandighede te behelp' (Fil 4:11, vgl. ook vers 12) by te werk.

In deel 5 (hfst. 15) spekuleer Gordon MacDonald wie Jesus se rabbi sou wees tydens sy jeug (vgl. bl. 194) en spekuleer verder dat sy 'ma 'n diepgaande invloed op sy ontwikkeling' moes gehad het en "n sterk en intelligente vrou' (bl. 195) was - dit alles, terwyl die Skrifbegronding dat Jesus van kleins af God én mens was en dus ook vervul is met die Heilige Gees en sy wysheid en toerusting, myns insiens, primêr van die God die Vader en die Heilige Gees kry, glad nie genoem word nie.

Daar is heelwat meer plekke wat roep om duideliker Skrifgronde.

Tog raak die boek praktiese sake oor die gelowige se oppadwees deur die lewe aan; laat dit jou dink en wéér dink en stimuleer die lees daarvan jou om verder en dieper in die Skrif te gaan delf oor hierdie lewenswerklikhede. 